\section{Gas Exchange Characteristics of Fragaria chiloensis Genotypes}

\author{
J. Scott Cameron ${ }^{1}$ and Carol A. Hartley ${ }^{2}$ \\ Washington State University Research and Extension Unit, 1919 N. E. \\ 78th Street, Vancouver, WA 98665-9752
}

Additional index words. Fragaria chiloensis, Fragaria $\times$ ananassa, strawberry, photosynthesis

\begin{abstract}
Twenty-five female clones of Fragaria chiloensis (L.) Duchesene collected from the California and Oregon coasts were surveyed for gas exchange rates under field conditions. Carbon assimilation (A) rates of native clones were $25 \%$ to $69 \%$ higher than for 'Totem' (Fragaria $\times$ ananassa Duchesne) on a leaf-area basis ( $\mu$ mol of $\mathrm{CO}$ per $\mathrm{sec} / \mathrm{m}^{2}$ ) and $7 \%$ to $77 \%$ higher when expressed on a leaf dry-weight basis $(\mu \mathrm{mol}$ of $\mathrm{CO}_{2}$ per $\mathrm{kg}$ dry wt/sec). Higher rates of stomatal conductance $\left(\mathrm{g}_{\mathrm{s}}\right)$ were observed in 16 of $25 \mathrm{~F}$. chiloensis clones than in 'Totem', with nine of 25 clones also having higher rates of transpiration $(E)$. All clones had higher rates of residual conductance $\left(g_{r}\right)$ and greater water use efficiency (WUE) than the cultivated standard. The gas exchange characteristics of four strawberry cultivars $(F . \times$ ananassa) and four $F$. chiloensis genotypes were compared under standard greenhouse conditions. $F$. chiloensis genotypes had higher rates of $A$ than cultivars when expressed on per leaf-area and dryweight bases. Native clones also had higher rates of $g_{s}, g_{r}, E$, and WUE and greater quantum yield. Differences in chlorophyll content were observed among genotypes, but not between species.
\end{abstract}

The native beach strawberry (Fragaria chiloensis) is one of the progenitor species of the cultivated strawberry (Fragaria $\times$ ananassa) and is an important resource for its genetic improvement. Strawberry breeders have considered $F$. chiloensis to be a source of traits such as insect and spider mite resistance $(2,14-$ 17), disease resistance $(1,3,12)$, and drought, salinity, and cold tolerance $(1,3)$, as well as various fruit characteristics (3). While ecological differentiation (7) and sexual dimorphism (8) have been studied in California populations of $F$. chiloensis, relatively little is known about the physiology of this species and what characteristics of its growth and development might be of value for genetic improvement of the strawberry. In preliminary field studies, we have observed that clones of $F$. chiloensis have higher rates of $\mathrm{CO}$, assimilation than cultivated genotypes (unpublished data).

In this study, we screened a collection of $F$. chiloensis clones for variability in gas exchange rates in the field; secondarily, we obtained preliminary data characterizing the differences in gas exchange characteristics

Received for publication 11 Aug. 1988. H/LA Paper no. 88-24. Project no. 0783, College of Agriculture and Home Economics Research Center, Pullman, WA 99164 . We gratefully acknowledge the financial support of the Washington Strawberry Commission and the Kay Mukai Research Foundation, Watsonville, Calif. The technical assistance of D.R. Mittelstadt and M.P. Rogers during the course of this study is greatly appreciated. The cost of publishing this paper was defrayed in part by the payment of page charges. Under postal regulations, this paper therefore must be hereby marked advertisement solely to indicate this fact. Assistant Horticulturist.

${ }^{2}$ Agricultural Research Technologist II. vested 10 days before this study. Measurements were made on single leaves from two plants within each matted plot, replicated over five blocks. The determinations were made on consecutive clear days (13-15 July 1987) between 0900-1300 HR (PDST) at a saturating photosynthetic photon flux (PPF) $(2200$ $\mu \mathrm{mol} \cdot \mathrm{s}^{-1} \cdot \mathrm{m}^{-2}$ ) with air averaging $26 \pm 3 \mathrm{C}$ and an ambient $\mathrm{CO}_{2}$ concentration of $338 \pm$ $4 \mathrm{ppm}$. Complete blocks were measured in turn to minimize the effects of environmental variability over time. No significant block effect was observed in the analysis.

Gas exchange measurements were made using a $\mathrm{CO}_{2}$ analyzer (Model LCA-2, Analytical Development Co., Hoddesdon, Herts, U.K.) equipped with a Parkinson broadleaf chamber and operated as an open system. Measurements were made on the middle leaflet of the third or fourth fully expanded leaf. Carbon dioxide depletion by a $6.25-\mathrm{cm}^{2}$ leaf area in the chamber was monitored for 30 to $60 \mathrm{sec}$ at a flow rate of 0.5 liter $\cdot \mathrm{min}^{-1}$. All gas exchange characteristics were calculated using standard equations described by Moon and Flore (9). Dry weight per leaf unit area in the chamber was calculated based on the mean dry weight of three $0.31-\mathrm{cm}^{2}$ leaf punches per leaf.

Greenhouse study. Gas exchange characteristics of four strawberry cultivars were compared to those of four $F$. chiloensis clones. The four cultivated genotypes, 'Benton', 'Hood', 'Olympus', and 'Totem', are commercially important in the Pacific Northwest. The four $F$. chiloensis genotypes, CL5, 'Del Norte', LCM-20, and ZB-19, have been identified as being resistant to one or more insect and/or arthropod pests $(2,15$ 17) and have been used in the Washington State Univ. strawberry breeding program.

Two-year-old plants of each genotype were grown in the greenhouse in $25-\mathrm{cm}$ pots $(10.9$ liters) containing a 2 peat : 1.5 perlite : 1 sand mixture (by volume). Plants were fertilized weekly with a complete $(20 \mathrm{~N}-20 \mathrm{P}-$ $20 \mathrm{~K}$ ) water-soluble fertilizer plus micronu-

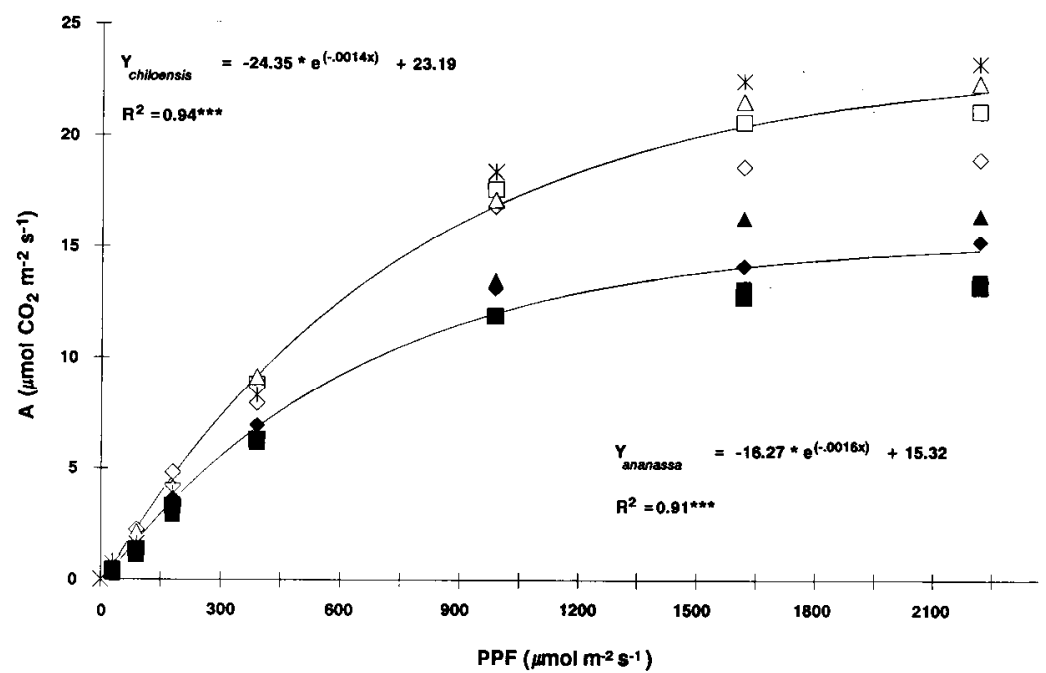

Fig. 1. Photosynthetic response of $F$. chiloensis (open symbols) and $F . \times$ ananassa (closed symbols) genotypes (listed in Table 3) to increasing photosynthetic photon flux (PPF). Measurements were made at an ambient $\mathrm{CO}_{2}$ concentration of $376 \pm 1 \mathrm{ppm}$ with the chamber at $25.6 \pm 2.5 \mathrm{C}$. Different symbols within a species represent different genotypes. 
Table 1. Locations of $25 \mathrm{~F}$. chiloensis collection sites in northern California and southern/central Oregon.

\begin{tabular}{lll}
\hline \hline Clone $^{2}$ & Location & California \\
\hline & & \multicolumn{1}{c}{ County } \\
A17 & Centerville Beach County Park & \\
B12 & Clam Park near Table Bluff Lighthouse & Humboldt \\
C19 & Trinadad Beach State Park & Humboldt \\
D2 & Big Lagoon County Park & Humboldt \\
E3 & Stone Lagoon Campground & Humboldt \\
F4 & Along U.S. 101 between Redwood Creek Beach Co. Park & Humboldt \\
& and Freshwater Lagoon & Humboldt \\
G5 & False Klamath Cove & \\
H9 & Point St. George & Del Norte \\
I14 & Kellog Beach & Del Norte \\
& & Del Norte \\
J19 & Undeveloped Oregon State Park along Oceanview Drive & \\
K18 & Harris Beach State Park & Curry \\
L11 & Whalehead Beach, Boardman State Park & Curry \\
M7 & Pistol River State Park & Curry \\
N6 & Beach access area north of Rogue River outlet & Curry \\
O16 & Battle Rock Wayside Park & Curry \\
P19 & Cape Blanco State Park & Curry \\
Q16 & Bullards Beach State Park & Curry \\
R5 & Horsfall, Oregon Dunes Recreation Area, & Coos \\
S3 & Siuslaw National Forest & Coos \\
& Siltcoos, Oregon Dunes Recreation Area, & Lane \\
T2 & Siuslaw National Forest & \\
U5 & Siuslaw Harbor Vista County Park & Lane \\
W15 & Ponsler Memorial Wayside & Lane \\
X16 & Seal Rock Wayside State Park & Lincoln \\
Y58 & Moolack Beach Wayside State Park & Lincoln \\
Z3 & Yachats State Park & Lincoln \\
Cloned & Lincoln \\
\hline
\end{tabular}

${ }^{2}$ Clones collected by C.H. Shanks, Jr., and T.M. Sjulin in 1983.

trients. Leaves used for measurements in this study matured under a maximum ambient PPF of $1100 \mu \mathrm{mol} \cdot \mathrm{s}^{-1} \cdot \mathrm{m}^{-2}$ at plant level with days ranging from 17 to $34 \mathrm{C}$ and nights from
17 to $25 \mathrm{C}$. Gas exchange measurements were made in the greenhouse under a high pressure sodium lamp with the ambient chamber at a mean temperature of $25.6 \pm 2.5 \mathrm{C}$ and an ambient $\mathrm{CO}_{2}$ concentration of $376 \pm 2$ ppm. Single leaflet measurements were made on four leaves from each of two plants of each genotype as described above, with a chamber flow rate of $0.5 \mathrm{liter} \cdot \mathrm{min}^{-1}$. Chlorophyll was extracted from three $0.31-\mathrm{cm}^{2}$ leaf punches in $5 \mathrm{ml}$ of $\mathrm{N}, \mathrm{N}$-dimethyl formamide and determined using the spectrophotometric assay described by Moran (11). The experiment was analyzed as a randomized block design with replication and nesting of treatments. Light response curves were generated by obtaining photosynthetic measurements at a saturating level of PPF (2200 $\mu \mathrm{mol} \cdot \mathrm{s}^{-1} \cdot \mathrm{m}^{-2}$ ) and then reducing PPF in stepwise increments with screen filters. Data were fitted by computer to an asymptotic curve of the form $y=a \times e^{b x}(10,13)$ using the Marquardt method of successive approximations (4).

In the field, $\mathrm{CO}_{2}$ assimilation (A) rates as expressed on a leaf-area basis ( $\mu \mathrm{mol}$ of $\mathrm{CO}_{2}$ per sec/m2) were significantly higher $(25 \%$ to $69 \%$ ) for all the native clones than for 'Totem' (Table 2). When expressed on a dryweight basis ( $\mu \mathrm{mol}$ of $\mathrm{CO}_{2}$ per kg dry wt/ sec), A was significantly greater than 'Totem' in 19 of $25 \mathrm{~F}$. chiloensis genotypes, with increases ranging from $7 \%$ to $77 \%$. Stomatal conductance $(\mathrm{g})$ was higher in 16 of 25 clones and residual conductance $(g)$ was higher in all clones of $F$. chiloensis than for the cultivated standard. Transpiration (E) rates were significantly higher in nine of the 25 native clones than in 'Totem', but all $F$. chiloensis genotypes had greater water use efficiency (WUE) than the cultivated standard. In the greenhouse, significant differences

Table 2. Gas exchange characteristics of $25 F$. chiloensis clones and the cultivar Totem in the field.

\begin{tabular}{|c|c|c|c|c|c|c|}
\hline \multirow[b]{2}{*}{ Clone } & \multicolumn{2}{|c|}{ A } & \multirow[b]{2}{*}{$\left(\mathrm{mmol} \cdot \mathrm{s}^{\mathrm{s}^{-1}} \cdot \mathrm{m}^{-2}\right)$} & \multirow[b]{2}{*}{$\left(\mathrm{mmo} \cdot \mathrm{g}_{\mathrm{r}} \cdot \mathrm{s}^{-1} \cdot \mathrm{m}^{-2}\right)$} & \multirow[b]{2}{*}{$\begin{array}{c}\mathrm{E} \\
\left(\mathrm{mmol} \cdot \mathrm{s}^{-1} \cdot \mathrm{m}^{-2}\right)\end{array}$} & \multirow{2}{*}{$\begin{array}{c}\text { WUE } \\
\left(\mathrm{mol} \mathrm{CO}_{2} / \mathrm{mol}^{-3}\right. \\
\left.\mathrm{H}_{2} \mathrm{O}\right) \times 10^{-3}\end{array}$} \\
\hline & $\left(\mu \mathrm{mol} \cdot \mathrm{s}^{-1} \cdot \mathrm{m}^{-2}\right)$ & $\begin{array}{c}\mu \mathrm{mol} / \mathrm{kg} \text { dry } \\
\text { wt per sec) }\end{array}$ & & & & \\
\hline A17 & 21.4 & 201 & 176 & 105 & 6.5 & 3.7 \\
\hline B12 & 17.7 & 161 & 146 & 88 & 5.4 & 3.7 \\
\hline $\mathrm{C} 19$ & 18.9 & 190 & 177 & 100 & 6.5 & 3.7 \\
\hline D2 & 17.4 & 186 & 141 & 87 & 4.8 & 3.6 \\
\hline $\mathrm{E} 3$ & 19.1 & 159 & 153 & 94 & 5.7 & 4.0 \\
\hline $\mathrm{F} 4$ & 22.9 & 193 & 194 & 111 & 7.1 & $\begin{array}{l}4.0 \\
3.8\end{array}$ \\
\hline G5 & 20.1 & 182 & 158 & 103 & 6.0 & 3.9 \\
\hline H9 & 20.5 & 176 & 182 & 95 & 6.2 & 4.0 \\
\hline $\mathrm{I} 14$ & 19.6 & 158 & 149 & 103 & 5.7 & 4.1 \\
\hline J19 & 19.8 & 176 & 177 & 98 & 5.9 & 4.0 \\
\hline K18 & 20.6 & 177 & 167 & 96 & 6.2 & 3.7 \\
\hline L11 & 21.3 & 261 & 205 & 96 & 5.4 & 3.4 \\
\hline M7 & 20.1 & 184 & 170 & 97 & 6.2 & 3.8 \\
\hline N6 & 21.7 & 201 & 188 & 103 & 6.6 & 3.7 \\
\hline 016 & 22.2 & 219 & 207 & 101 & 6.7 & 3.8 \\
\hline P19 & 23.0 & 214 & 191 & 112 & 5.1 & $\begin{array}{l}5.0 \\
3.9\end{array}$ \\
\hline Q16 & 19.5 & 211 & 150 & 102 & 6.1 & 3.8 \\
\hline $\mathrm{R} 5$ & 20.8 & 224 & 168 & 103 & 5.2 & 4.1 \\
\hline$\overline{\mathrm{s3}}$ & 17.0 & 189 & 127 & 93 & 5.2 & 3.8 \\
\hline & 18.9 & 212 & 149 & 94 & 5.9 & 3.7 \\
\hline U5 & 19.1 & 236 & 157 & 94 & 5.5 & 4.0 \\
\hline W15 & 19.6 & 205 & 148 & 103 & 5.4 & 4.0 \\
\hline$X 16$ & 21.5 & 218 & 198 & 98 & 6.7 & 3.8 \\
\hline Y58 & 17.5 & 203 & 153 & 82 & 5.8 & 3.5 \\
\hline $\mathrm{Z3}$ & 19.5 & 254 & 168 & 93 & 53 & 37 \\
\hline 'Totem' & 13.6 & 148 & 121 & 65.4 & 4.6 & 3.0 \\
\hline \multirow{2}{*}{$\begin{array}{l}\text { Dunnett's } \\
\text { q statistic }(P<0.05)\end{array}$} & & & & & & \\
\hline & 2.8 & 34.5 & 32.8 & 11.7 & 1.6 & 0.3 \\
\hline
\end{tabular}

${ }^{2}$ Carbon dioxide assimilation (A), stomatal conductance to $\mathrm{CO}_{2}\left(\mathrm{~g}_{\mathrm{s}}\right)$, residual conductance to $\mathrm{CO}_{2}\left(\mathrm{~g}_{\mathrm{f}}\right)$, transpiration (E), and water use efficiency (WUE) were measured at a saturating PPF of $2200 \mu \mathrm{mol} \cdot \mathrm{s}^{-1} \cdot \mathrm{m}^{-2}$, ambient $\mathrm{CO}_{2}$ concentration of $338 \pm 4 \mathrm{ppm}$, and a temperature of $26 \pm 3 \mathrm{C}$. 
Table 3. Gas exchange and chlorophyll characteristics ${ }^{2}$ of $F$. chiloensis clones and strawberry cultivars in the greenhouse.

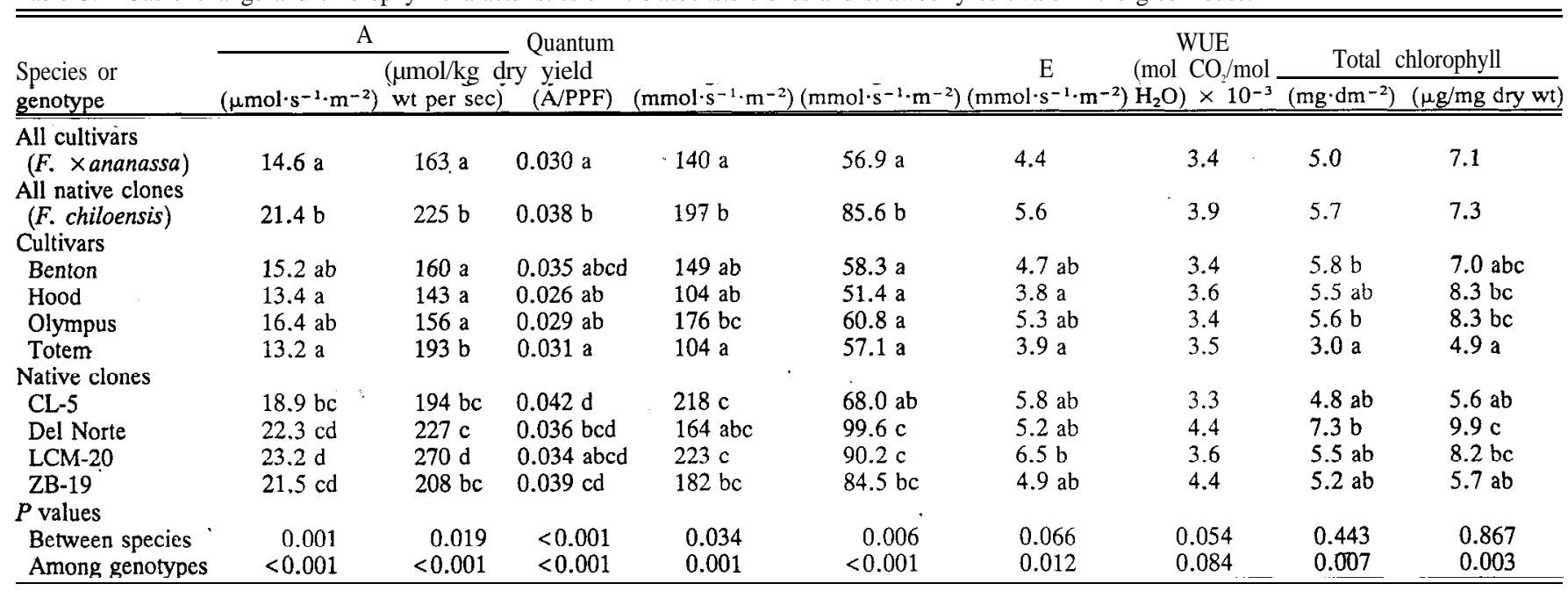

Carbon dioxide assimilation (A), stomatal conductance to $\mathrm{CO}_{2}(\mathrm{~g})$, residual conductance to $\mathrm{CO}$, (g,), transpiration (E), and water use efficiency (WUE) were measured at a saturating PPF of $2200 \mu \mathrm{mol} \cdot \mathrm{s}^{-1} \cdot \mathrm{m}^{-2}$, ambient $\mathrm{CO}_{2}$ concentration of $376 \pm 1 \mathrm{ppm}$, and a temperature of $25.6 \pm 2.5 \mathrm{C}$.

'Mean separation within columns by HSD, $5 \%$.

in $\mathrm{CO}_{2}$ assimilation rates were observed between species and among genotypes within species (Table 3). Rates of $\mathrm{A}, \mathrm{g}_{\mathrm{s}}$, and $\mathrm{g}_{\mathrm{r}}$ for $F$. chiloensis were significantly higher than those of cultivated genotypes; similar trends were observed for $\mathrm{E}(P=0.066)$ and WUE $(P=0.054)$. Chlorophyll content differed among genotypes but not between species.

The response of both species to increasing levels of PPF is presented in Fig. 1. Apparent quantum yield (as represented by the slope of the linear portion of the light response curve) was significantly greater $(P<0.001)$ for native vs. cultivated Fragaria (Table 3 ).

We do not know the basis for the higher rates of gas exchange of $F$. chiloensis clones than of cultivated genotypes. Leaves of $F$. chiloensis have a thick cuticle and recessed stomata; factors important' in drought tolerance (3). It is not clear whether anatomical factors played a significant role in the differences in WUE and A observed in this study. Greater rates of $\mathrm{CO}_{2}$ assimilation on a leaf dry-weight basis and greater rates of residual conductance may indicate that some $F$. chiloensis genotypes have a greater photosynthetic capacity than cultivated genotypes, but further studies are required to determine the nature of these differences.

Breeding for improved crop yields by direct genetic enhancement of photosynthetic processes has not been a successful strategy (5). The primary component of crop yield, which is open to modification by plant breeders, is partitioning of photoassimilates to economically important sinks (6). Thus, although $F$. chiloensis genotypes may have higher rates of net photosynthesis, ongoing evaluations of carbon partitioning patterns and resulting yield component interactions will be of primary importance in determining the breeding value of this germplasm.

\section{Literature Cited}

1. Bringhurst, R.S., J.F. Hancock, and V. Voth 1977. The beach strawberry, an important natural resource. Calif. Agr. 31:10.

2. Crock, J.E., C.H. Shanks, Jr., and B.H Barritt. 1982. Resistance in Fragaria chiloensis and $F . \times$ ananassa to the aphids Chaetosiphon fragaefolii and C. thomasi. HortScience 17:959-960.

3. Darrow, G.M. 1966. The strawberry. Holt, Rinehart, and Winston, New York.

4. Draper, N.R. and H. Smith. 1981. Applied regression analysis. 2nd ed. Wiley, New York.

5. Gifford, R.M. and C.L.D. Jenkins. 1983. Carbon metabolism and plant productivity, p. 419. In: Govindjee (ed.). Photosynthesis vol. 2. Academic, New York.

6. Gifford, R.M., J.H. Thorne, W.D. Hitz, and R.T. Giaguinta. 1984. Crop productivity and photoassimilate partitioning. Science 225:801-807.

7. Hancock, J.F., Jr., and R.S. Bringhurst. 1979. Ecological differentiation in a perennial, octoploid species of Fragaria. Amer. J. Bot. 66:367-375

8. Hancock, J.F. and R.S. Bringhurst. 1980 Sexual dimorphism in the strawberry Fragaria chiloensis. Evolution 34:762-768.

9. Moon, J.W. and J.A. Flore. 1986. A basic computer program for calculation of photo- synthesis, stomatal conductance and related parameters in an open gas exchange system. Photosyn. Res. 7:269-279.

10. Moon, J.W., J.F. Flare, and J.F. Hancock, Jr. 1986. A comparison of carbon and water vapor gas exchange characteristics between a diploid and highbush blueberry. J. Amer. Soc: Hort. Sci. 112:134-138.

11. Moran, R. and D. Porath. 1980. Chlorophyll determinations in intact tissues using N, N-dimethylformamide. Plant Physiol. 65:478-479.

12. Newton, W. and M.L.J. Van Adrichem. 1958. Resistance to Verticillium wilt in $\mathrm{F}_{1}$ generations of self-fertilized species of $\mathrm{Fra}$ garia. Can. J. Bot. 36:297-299.

13. Sams, C.E. and J.A. Flore. 1982. The influence of age, position and environmental variables on net photosynthetic rate of sour cherry leaves. J. Amer. Soc. Hort. Sci. 107:339-344.

14. Shanks, C.H., Jr., and B.H. Barritt. 1974. Fragaria chiloensis clones resistant to the strawberry aphid. HortScience 9:202-203.

15. Shanks, C.H., Jr., and B.H. Barritt. 1975. Resistance of strawberries to the twospotted spider mite. J. Econ. Entomol. 68:7-10.

16. Shanks, C.H., Jr., and R.P. Doss. 1986. Black vine weevil (Coleoptera: Curculionidae) feeding and oviposition on leaves of weevil-resistant and -susceptible strawberry clones presented in various quantities. Environ. Entomol. 15:1074-1077.

17. Shanks, C.H., Jr., D.L. Chase, and J.D. Chamberlain. 1984. Resistance of clones of wild strawberry, Fragaria chiloensis, to adult Otiorhynchus sulcatus and $O$. ovatus (Coleoptera: Curculionidae). Environ. Entomol. 13:1042-1045. 